\title{
Developing Student Worksheet Oriented to Science Literacy in Chemical Bonding Matter to Train Student's Science Literacy Ability in Senior High School
}

\author{
Puput Fuzi Adytia, Kusumawati Dwiningsih* \\ Departement of Chemistry \\ Universitas Negeri Surabaya \\ Surabaya, Indonesia \\ kusumawatidwiningsih@unesa.ac.id
}

\begin{abstract}
This study aims to describe the validity and practicality of developed scientific literacy worksheets. The validity of worksheets is reviewed based on contents and concepts, while the practicality of the worksheet is reviewed based on student responses supported by observations of student activities. This study uses the 4-D development model Thiagarajan et al. (1974). The student worksheet will be piloted to 15 students of SMAN 1 Gedeg Mojokerto. The results showed that student worksheets is said to be valid both in content and construct. The percentage of content validity obtained is between $80 \%$ to $93.33 \%$ in the valid and very valid categories. The percentage of construct validity is between $\mathbf{7 3 \%}$ to $93.33 \%$ in the valid and very valid categories. Students give a positive response to the developed worksheets. The percentage obtained between $73 \%$ and $100 \%$ in the response and very responding category. Based on the results obtained, it can be concluded that the worksheet oriented to scientific literacy in the material of valid and practical chemical bonding is used as teaching material to train students' scientific literacy.
\end{abstract} bond

Keywords - student worksheet, scientific literacy, chemical

\section{INTRODUCTION}

In the current technological era, people life continues to develop and change. The life of modern society today is very dependent on technology and the science. The development of knowledge will be achieved along with the development of education that is applied. The development of science will later be used to understand the environment, health, economy, and the problems faced. Therefore, the education applied is expected to be able to increase the competencies needed by students to be able to fulfill their life's needs in all changes in the situation. The students' competencies will be able to shape themselves to learn more and be useful for themselves and the life of people who are influenced by the development of science and technology [1].

Education that is able to form individuals who want to learn more and provide benefits for themselves and society will be achieved if each individual learner has scientific literacy skills. The word scientific literacy derives from the word Literatus and scientia. Literatus means letters, literacy, and education. While scientia means science knowledge [1]. The definition of science literacy according to PISA 2015 is the ability to use science knowledge, identify questions, and draw conclusions based on data or evidence, to understand and make decisions related to nature and its changes. According to PISA 2015, scientific literacy consists of domains that can be used as an assessment of one's scientific literacy abilities. These domains are domains of knowledge, context, competence, and attitude. Knowledge domain consists of content, proceed, and epistemic knowledge. The competency domain consists of explaining scientific phenomena, evaluating, designing scientific investigations, interpreting data and concluding conclusions. Attitude domains consist of interest in science, valuing approaches through scientific inquiry and environmental awareness. The three domains are packaged in a context that consists of personal, local/national, and global [2].

The domains of scientific literacy will form individuals who are critical, innovative, creative, and competitive in the world of work, and able to survive and resolve problems faced regarding scientific technological aspects. Student's knowledge will build content aspect of scientific literacy, content knowledge is scientific knowledge that important to human life and environment, natural resources, human health, limit of science and technology application. Scientific literacy will form individual that ready and have participant in discussion about social problems. Scientific literacy also can increase student ability to take an important decision in their life. Component of scientific literacy included scientific process, way of thinking, and practice that interconnected to find admission scientific solution, explain scientific phenomena used scientific evidence to take conclusion and implication, et al. [12].

However, Indonesian students' scientific literacy skills are still relatively low. Based on the results of the prestudy conducted at SMA Negeri 1 Gedeg Mojokerto stated that scientific literacy skills for several domains are knowledge, competence and context of students on average classified as poor and not good. In the domain of 
knowledge, $28.20 \%$ students are still lack in compiling scientific experiments. In addition, the results of the prestudy also informed that $46.67 \%$ of students did not understand the benefits of the material learned in class in daily life. According to TIMSS, the low level of literacy skills of Indonesian students can be influenced by the quality of the school, the curriculum, and the quality of teaching [1]. Some studies show that the ability of teachers to apply science learning that is in accordance with the nature of science is still very weak. One of the studies that support this statement is the research conducted by Budiastra found that increasing the ability of teachers in planning learning and teaching science through inquiry [1]. These conditions demand an improvement in the science learning process carried out at school.

Improvements can be started by compiling learning that is well prepared. In this case the teacher can choose the appropriate learning method and source as one solution to train scientific literacy. Student learning resources that are able to train scientific literacy skills are learning resources that are able to meet scientific literacy assessment criteria, among others: contain concepts that are broader than the concepts required in the curriculum, contain information in various forms of presentation that must be processed in advance by students who will answer it, scientific literacy questions must make students process information in questions, then the questions can be in the form of multiple forms such as multiple choice, essay, or even the contents and questions of scientific literacy must include context application. Material selection in training scientific literacy will also influence. Therefore, the selection of the material used is based on PISA 2015 relating to the content knowledge domain.

In PISA 2015, the content used has a principle that the concept being tested must be relevant to the real situation of daily life [2]. The material also has a very close relationship with our daily lives and that this concept is an important knowledge that long-term use. Based on these two principles, one material that is suitable to use is chemical bonding material. This is because the material of chemical bonds is closely related to everyday life. One real example is the fact that sugar is easily melted when heated. These properties turned out to have links to the chemical bonds that make up sugar.

In addition, chemical bonds also fulfill the second principle. This is because in the basic competencies that is to be achieved, this material explains the differences in ionic bonds, covalent bonds, coordination covalent bonds and metal bonds and their relation to the nature of substances. These concepts will certainly still be used for several years to come because in reality the theory of chemical bonding can be used as a basis for consideration of the selection and development of a material such as building materials because chemical bonds can affect the nature of a substance.

Based Solfarina [13] said that chemical bonding material have characteristic that are abstract because it included microscopic level that can't observed, like process of ionic bonding and covalent bonding formation. The matter also has principles formation of cation, anion, covalent compound, ionic compound those need to be awarded by students. Chemical bonding matter also very applicable because it can used to explain that relate with chemical bonding. The problems of course not far from daily life. Based on the pre-study conducted at SMA Negeri 1 Gedeg Mojokerto shows that $63.34 \%$ of students experience difficulties in the material. One of the reasons is that chemical bonds are a lot of memorized material and only contain abstract theories. Even $60 \%$ of students said they did not know the benefits of studying chemical bonds. Based on the results of interviews the chemistry teacher stated that during this time the material of chemical bonds was only taught theories without the existence of practicum that could support students' understanding.

Based on the problems described, the delivery of material on chemical bonds requires good planning in order to train scientific literacy. Preparations are made to prepare learning tools that can train students' scientific literacy. Based on research conducted by Vienurillah, it is shown that the development of appropriate scientific literacy worksheets in submersion of factors that influence the rate of reaction can improve the scientific literacy of students [3]. The results of this study show that the literacy ability of students who initially got an average score of 1.92 with an incomplete category in the pretest then experienced an increase that students got an average score of 2.90 with the complete category when posttest. Therefore, the researcher develops a tool in the form of a decent scientific literacy worksheet so that it can train scientific literacy in the material of chemical bonding. The other research conducted by Aisha [10], it is shown that student worksheet oriented scientific literacy developed is feasible as learning media. This research used 4D method. Result of this research are theoretic feasibility of student worksheet in content criteria is $86.27 \%$. The percentage of feasibility in presentation criteria is $87.18 \%$, and in language criteria is $86.67 \%$. But, in this student worksheet develop minimum of material from other literacy like scientific article that relate material. In the research conducted by Nawangati [11], it shows that the Student worksheet is oriented scientific literacy can train literacy skills in good and theoretical material. Research conducted by Ramdaniyah [15] showed that learning using science literacy worksheets applied with guided inquiry models was able to improve students' scientific literacy skills, especially for competency domains. The results showed an increase in each literacy, namely a phenomenon that explained the actual occurrence of 0.64 with moderate conv. 0.78 with high criteria.

The developed worksheets are made as attractive as possible and contain problems related to chemical bonds that are interesting and include domains of scientific literacy, namely context, competence, knowledge and attitude. The problems listed in student worksheets are problems that occur in everyday life where in the solution can be searched by applying the theory of chemical bonds obtained at school. This worksheet is expected to motivate students to learn and can train students' scientific literacy so students are ready to face the demands of the outside world today.

The development of appropriate scientific literacy worksheets will be reviewed based on validity and practicality. The validity of student worksheets is reviewed based on content and structure. Content validity 
includes suitability with the Basic Competencies proposed by the curriculum, suitability with students' cognitive development, correctness of substance and material, and conformity with all four domains of scientific literacy including domains of knowledge, competence, context, and attitude. The construct validity assessment is reviewed based on presentation, graphics and language such as clarity goals to be achieved, order of presentation, display design, layout, effective use of Indonesian language, motivation and attractiveness, etc. The practicality of the student worksheets will be reviewed based on ability can lead to interest and interest for students, ease of use, and ability to motivate students to learn.

\section{METHOD}

Development of scientific literacy worksheets on chemical bonding material using the 4-D development model by Thiagarajan et al. [4] This model consists of 4 stages, namely define, design, develop, and disseminate. But in this study is restricted to the stages develop (development). The phase diagram of the development of scientific literacy worksheets on chemical bonding material is shown in Figure 1.

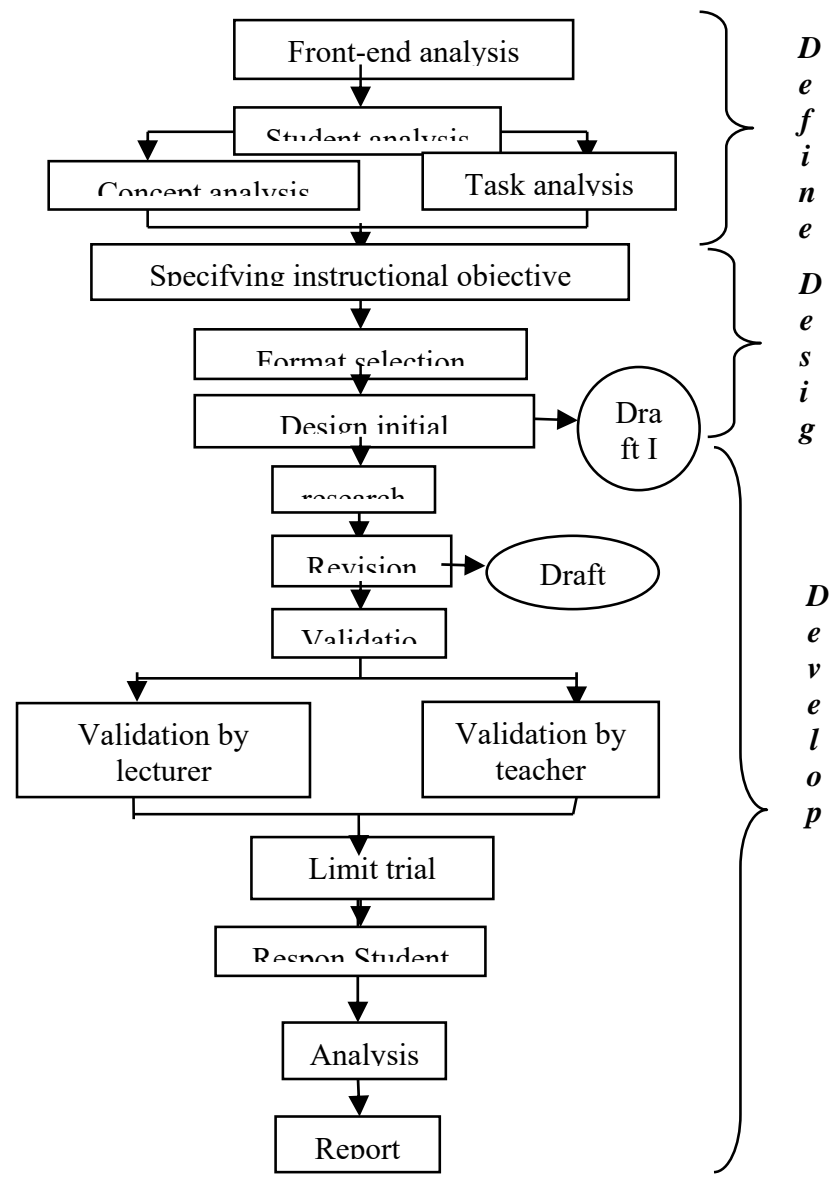

Fig 1. Stages Diagram for Developing Student-Oriented Science Literacy worksheets on Chemical Bonding Material

The instruments used to determine the validity of the worksheets developed are the study sheet and validation sheet. Review sheets are used to provide suggestions / input for student worksheet. The input provided is in terms of both content and construct. Scientific literacy worksheets are reviewed by a chemistry lecturer and validation sheets are used to provide an assessment of student worksheets in terms of both content and constructs. The instrument used to determine the practicality of the developed worksheets was a student response questionnaire that would be given to 15 students at the end of the trial activity. This response questionnaire statement was supported by an observation sheet of student activity so that the data obtained was more accurate.

The results of the study data were then analyzed descriptively. The results of the study were then used to correct the lack of scientific literacy worksheets on the material of chemical bonding so that draft II was obtained. After repairs, the student worksheet was validated by 2 chemistry lecturers and 1 chemistry teacher at SMAN 1 Gedeg Mojokerto. The validation results data were analyzed quantitatively descriptively. The results of the analysis of each criterion will be presented in the form of a percentage based on the calculation of the Likert scale in Table 1. TABLE.1 LIKERT SCALE

\begin{tabular}{|c|c|}
\hline Category & Scale \\
\hline Very good & 5 \\
\hline Good & 4 \\
\hline Medium & 3 \\
\hline Bad & 2 \\
\hline Very bad & 1 \\
\hline
\end{tabular}

The formula used in calculating the validation results to obtain percentages is:

$$
\%=\frac{\text { score total all validator every criteria }}{\text { score criterium }} \times 100 \%
$$

Criterion score $=$ highest score per item $\mathrm{x}$ number of aspects $\mathrm{x}$ number of respondents Then the results of the calculation are interpreted in accordance with Table 2.

TABLE 2. INTERPRETATION CRITERIA SCORE

\begin{tabular}{|c|c|}
\hline Scale & Category \\
\hline $0 \%-2 \%$ & Very bad \\
\hline $25 \%-40 \%$ & Bad \\
\hline $41 \%-60 \%$ & Medium \\
\hline $61 \%-80 \%$ & Valid \\
\hline $81 \%-100 \%$ & Very valid \\
\hline
\end{tabular}

The results of the student response questionnaire data will also be processed in a quantitative descriptive manner. The results of the response questionnaire are presented in percentage form based on Guttman scale calculations in table 3.

TABLE 3 GUTTMAN SCALE

\begin{tabular}{|c|c|c|}
\hline Question & Answer & Score \\
\hline \multirow{2}{*}{ Positive } & Yes & 1 \\
\cline { 2 - 3 } & No & 0 \\
\hline \multirow{2}{*}{ Negative } & Yes & 0 \\
\cline { 2 - 3 } & No & 1 \\
\hline
\end{tabular}


The data obtained is calculated by the formula:

$$
P=\frac{\mathrm{F}}{\mathrm{N}} \times 100 \%
$$

Description:

$\mathrm{P}=$ percentage of respondent's answers

$\mathrm{F}=$ number of answers "yes" to positive questions or number of "no" answers to negative questions

$\mathrm{N}=$ number of respondents

The results of this student response questionnaire analysis are then categorized into the appropriate score interpretation criteria in table 4 below.

TABLE 4 INTERPRETATION CRITERIA SCORE FOR STUDENT RESPONSE

\begin{tabular}{|c|c|}
\hline Percentage & Category \\
\hline $0 \%-20 \%$ & Very less respond \\
\hline $21 \%-40 \%$ & Less respond \\
\hline $41 \%-60 \%$ & Respond enough \\
\hline $61 \%-80 \%$ & Respond \\
\hline $81 \%-100 \%$ & Respond very strongly \\
\hline
\end{tabular}

The results of the response questionnaire are supported by the results of observations of student activities. This analysis is used to find out the activities of students during the learning process using developed worksheets. The percentage of student activity is obtained through percentage calculations. The calculation formula is used as follows

Student activity $(\%)=$

E Frequency studení s activity appear

Z tatal frequency student's acturty appear $\times 100 \%$

\section{RESEARCH AND DISCUSSION}

Development of Student Activity Sheet oriented to scientific literacy in this chemical bond material using the 4-D method that is define, design, develop, and disseminate. But in this study only arrived at the develop stage. Each of these stages consists of several steps. The following are the steps taken in developing student worksheets.

\section{A. Defining (Define)}

\section{1) Front- end Analysis}

This front end analysis includes an analysis of the curriculum and demands in the future. The curriculum used in SMAN 1 Gedeg Mojokerto is the revised 2013 curriculum. Science literacy can be trained by adjusting the 2013 curriculum demands, namely on the basic competency 3.5 that students are expected to be able to compare ionic bonds, covalent bonds, covalent bonds, coordination, and metal bonds and their relation to the nature of substances. In addition, basic competence 4.5, namely students are required to design and conduct experiments to show the characteristics of ionic compounds or covalent compounds based on several physical properties [6].

Basic competencies 3.5 train the domain of scientific literacy knowledge. Based on these basic competencies, the worksheets are arranged by displaying phenomena and students are asked to identify the type of bond by connecting the concepts with one another related to ionic bonds and covalent bonds.

Basic competence 4.5 with indicators that students can design and conduct experiments to show the characteristics of ionic and covalent compounds based on their physical properties and students conduct experiments to show the characteristics of ionic and covalent compounds. These indicators are in accordance with the competency domain because students are trained to have competence in evaluating and designing scientific investigations. Therefore, student worksheets are prepared by training students to design experiments based on a scientific phenomenon. In addition, this indicator also reflects the attitude domain that is located when experimenting. The attitudinal domain is an appreciation of scientific inquiry and an interest in science. Finally, the context domain is contained because in the experiment, students will know the usefulness or application of the knowledge they have learned.

\section{2) Student Analysis}

The things that are analyzed include the characteristics of students, namely students' cognitive development and the scientific literacy abilities of students related to learning material. Worksheets are developed taking into account the cognitive development of students so that students can solve the problems presented. Students can reason logically and think abstractly by linking the material learned in the classroom to the application of science. The test results of scientific literacy questions that were carried out before students worksheets were developed showed that students' scientific literacy skills at SMAN 1 Gedeg Mojokerto tended to be poor. Based on the results of the questionnaire distributed, it also shows that $60 \%$ of students do not know the benefits of learning chemical bonds for everyday life.

\section{3) Concept Analysis}

Researchers identify the main concepts that students will learn, compile them in the hierarchy and break them down into concepts that will be studied. Based on the curriculum, students are expected to be able to distinguish between types of ionic and covalent bonds. The concept of ionic bonds contained in the students worksheets is in the form of reading material supported by practice questions to deepen understanding of the concept. The concepts taught in ionic bonds include ions, ionic bonds, cations, and anions. In submersion covalent bonds, the concepts to be taught are covalent bonds, single covalent bonds, duplicate, triplicate, polar covalent bonds, and non-polar covalent bonds. 


\section{4) Task Analysis}

In this step, scientific literacy skills are identified which include 4 domains. The analysis is done by detailing the scientific literacy domains that will be trained which are directly combined with the material in the form of an outline. The basic competencies that have been determined in the 2013 curriculum are elaborated in detail into several indicators that are associated with the domains of scientific literacy.

\section{5) Formulation of Learning Objectives}

Concept analysis and task analysis are changed into goals to be achieved. The learning objectives to be achieved for students are as follows:

(i) Students can determine the ionic bond and the covalent bond that is owned by a compound that is presented in the phenomenon correctly.

(ii) Students can explain the formation of ionic bonds and the covalent bond of a compound that is presented in the phenomenon correctly.

(iii) Students can explain the nature of substances related to ionic bonds and covalent bonds based on phenomena in daily life correctly.

(iv) Students design experiments to prove that the characteristics of ionic compounds or covalent compounds can influence several physical properties based on well-presented images.

(v) Students can conduct experiments to prove the characteristics of ionic compounds or covalent compounds based on several physical properties based on the design that has been prepared in advance properly and correctly.

\section{B. Planning (Design)}

\section{1) Selection Media}

The selection of media and equipment is adjusted to the objectives to be achieved. Based on the goals that have been determined, the researcher chooses student worksheets which will be developed as a learning tool that bridges the achievement of goals.

\section{2) Format selection}

When compiling student worksheets, we need to pay attention to several things, namely the appearance, easy language, test understanding, stimulants, ease of reading, and instructional material (selection of study materials). Therefore, by considering these matters, the format chosen for compiling science literacy oriented worksheets is the title, basic competencies to be achieved, information about bonding material, work steps such as the use of worksheets, tasks to be carried out along with instructional sentences in workmanship [7].

\section{Designing the initial design}

The student worksheets are sheets containing titles, basic competencies to be achieved, instructions, supporting information, tasks and work steps, and assessment, the student worksheets developed will consist of three main parts, namely introduction, content, and closing. The introductory section includes the title, basic competencies to be achieved, and instructions. The contents section consists of supporting information, tasks and work steps. The closing section is a bibliography and attachments. Display of student worksheets regarding one domain of scientific literacy is shown in Figure 2.

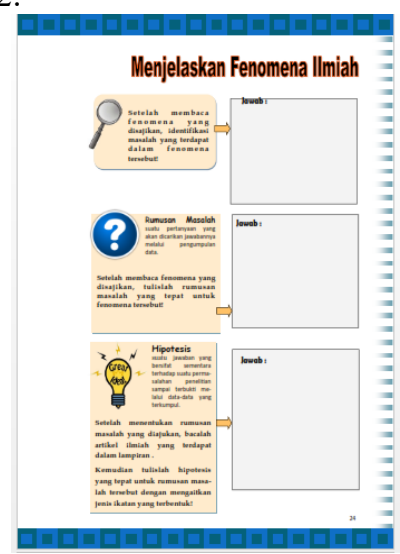

Fig 2. Display of competency domain in student worksheets

\section{Development ( Develop)}

\section{1) Review and Validation}

At the review stage, the reviewers gave some of their dynamics input on the layout, the appearance of the student worksheets to make it more dancing and choosing the color of the writing that corresponded to the background color. The design of the appearance of attractiveness in the location is important to note because it can motivate students in learning [7]. Enter other forms of truth in the phenomena used in student worksheets so as not to make misconceptions for students and the preparation of learning objectives contained in the student worksheets in accordance with the principles of Audience, Behavior, Condition, and Degree. This is because the preparation of the right objectives will determine the preparation of the material in the student worksheets therefore the learning objectives used must be clear [7].

After the student worksheets was reviewed and corrected, Draft II was obtained, which was then validated by chemistry lecturers and teachers. The validity of student worksheets is viewed from the content and structure [8]. Content validation contains several aspects including suitability with the curriculum, suitability with the child's age development, compatibility with the domains of scientific literacy, and the truth of the substance of the material. The construct validation is seen based on presentation, graphics, and language [7]. Validation results are shown in table 5 .

TABLE 5 RESULTS OF VALIDATION OF CONTENTS AND CONSTRUCTS OF STUDENT WORKSHEETS

\begin{tabular}{|c|c|c|}
\hline \multicolumn{3}{|c|}{ Aspect Language } \\
\hline Assessed criteria & $\%$ & Category \\
\hline Clarity of information & $73.33 \%$ & Valid \\
\hline
\end{tabular}




\begin{tabular}{|c|c|c|}
\hline $\begin{array}{l}\text { Compliance with language rules } \\
\text { Indonesia is good and right }\end{array}$ & $80 \%$ & Valid \\
\hline Clear and concise language use & $86.67 \%$ & Very valid \\
\hline \multicolumn{3}{|c|}{ Aspect Graph } \\
\hline Assessed criteria & $\%$ & Category \\
\hline font usage, type and size & $86.67 \%$ & Very valid \\
\hline display design & $93.33 \%$ & Very valid \\
\hline lay out or layout & $93.33 \%$ & Very valid \\
\hline \multicolumn{3}{|c|}{ Aspect Presentation } \\
\hline Assessed criteria & $\%$ & Category \\
\hline $\begin{array}{c}\text { Clarity of the objectives to be } \\
\text { achieved }\end{array}$ & $83.33 \%$ & Very valid \\
\hline Serving order & $86.67 \%$ & Very valid \\
\hline Giving motivation and attractiveness & $80 \%$ & valid \\
\hline Complete information & $86.67 \%$ & Very valid \\
\hline Interaction & $73.33 \%$ & valid \\
\hline \multicolumn{3}{|c|}{ Fill in } \\
\hline Assessed criteria & Percentage & Category \\
\hline Compliance with basic competence & $91.11 \%$ & Very valid \\
\hline $\begin{array}{c}\text { Conformity with children's cognitive } \\
\text { development }\end{array}$ & $80 \%$ & valid \\
\hline Conformity with material substance & $86.67 \%$ & Very valid \\
\hline Conformity with scientific literacy & $82 \%$ & Very valid \\
\hline
\end{tabular}

Based on Table 5 shows that the percentage for suitability of student worksheets with Basic Competence is $91.11 \%$, very valid. The material included in the worksheets has been adapted to the curriculum which states the basic competencies for class $\mathrm{X}$ chemistry one of them is 3.5 Comparing the process of formation of ionic bonds, covalent bonds, covalent bonds of coordination, and metal bonds and the interaction between particles (atoms, ions, molecules) relation to the physical nature of matter [6]. However, in this study the material was limited to submersion of ionic bonds and covalent bonds and their relationship to the physical properties of matter.

In the suitability criteria with students' cognitive development, $80 \%$ results are obtained. The student worksheets developed was adapted to Piaget's cognitive development theory, that at that age the child was in the formal operational stage so that he could think abstractly, had reasoned thinking, and made conclusions based on the data he had [9]. It's just that this ability needs to be trained. Therefore, it is appropriate that high school student of class $\mathrm{X}$ to be given scientific literacy worksheets on chemical bonding material. Among other aspects, aspects of conformity with students' cognitive development get the lowest results. The low percentage results are because the developed worksheets are considered less considering the determination of the phenomena raised. One of the phenomena raised in student worksheets is a phenomenon that is too foreign to students. According to Nasution, experiences that are too foreign to children will affect the student accommodation process. The inhibition of this accommodation process will affect students' cognitive development [1].

The developed worksheet is said to be $82 \%$, very valid for conformity with scientific literacy. The worksheet requires students to know the conditions in which a situation occurs or the application of the concept of chemical bonding occurs. The scope of the phenomena related to chemical bonds is personal, national, and global. However, $18 \%$ of the validator's assessment said that student worksheets was lacking because the scope used was too focused on the personal and national context. As for global issues, they have not been properly represented.

On the presentation criteria, the interaction aspect means providing stimulus and response to students. The provision of stimulus means stimulating students to do learning in accordance with what is expected in basic competence and learning goals [1]. Because of that students are stimulated by adjusting chemical characteristics in daily life. The material learned is related to everyday life so that it stimulates students to learn it. However, the interaction aspect is the lowest aspect of assessment. Based on Table 5 shows that $26.66 \%$ assessed student worksheets developed can't provide good stimulus because there are phenomena that do not provide usefulness to students in everyday life so that it affects the activeness of students to learn it [1].

On linguistic criteria, it is known that the clarity of information gets a percentage of $73.33 \%$. This percentage is classified as valid and $26.67 \%$ is declared invalid [5]. This invalidity is due to the use of terms that are considered quite foreign to high school students of class $\mathrm{X}$ such as the term demineralization, $\mathrm{pH}$, and refractory. The use of the term should consider several aspects of student development so that it can be easily understood [1]. In aspects of the use of clear and concise language included in the category of very valid. Aspects of the use of clear and concise language get the highest percentage compared to other aspects because the student worksheets developed has been in accordance with the Ministry of National Education which states that in the preparation of the sentence made not too long. The number of words used is not more than 25 words and for one paragraph the number of sentences used is 3-7 sentences [7].

In the graphics criteria, aspects of font usage, type and size, layout or layout, and display design successively obtain $86.67 \% ; 93.33 \%$; and $93.33 \%$. The use of fonts, types and sizes in the Worksheet is in accordance with the requirements for the preparation of printed teaching materials proposed by Steffen-Peter Ballstaedt, namely ease of reading which includes the use of letters that are not too small and easy to read [7]. However, the validator rate of $13.33 \%$ is declared invalid because some writings on student worksheets use a font size that is considered too small. 2) Limited trials. Limited trials were conducted at SMA Negeri 1 Gedeg Mojokerto. The sample taken was 15 students. This trial is used to find out the practicality of the developed worksheets. According to Nieveen and Toharudin \& Hendrawati, it is explained that worksheets oriented to literacy in the material of chemical bonds are said to be practical if they meet aspects that can generate interest and interest for students, easy to use, and can motivate students to 
learn. The results of the response questionnaire obtained the results shown in Table 6 .

TABLE. 6 RESULTS OF QUESTIONNAIRE RESPONSES TO SCIENTIFIC LITERACY WORKSHEETS

\begin{tabular}{|c|c|c|c|}
\hline No. & Aspect & $\%$ & Category \\
\hline 1. & $\begin{array}{c}\text { Messages in student } \\
\text { worksheets are in accordance } \\
\text { with the material studied }\end{array}$ & 100 & $\begin{array}{l}\text { Respond very } \\
\text { strongly }\end{array}$ \\
\hline 2. & $\begin{array}{l}\text { Worksheets can be understood } \\
\text { with young people }\end{array}$ & 80 & Respond \\
\hline 3. & $\begin{array}{l}\text { Experiment activities in } \\
\text { student worksheets provide a } \\
\text { real picture of the material }\end{array}$ & 100 & $\begin{array}{l}\text { Respond very } \\
\text { strongly }\end{array}$ \\
\hline 4 & $\begin{array}{l}\text { The language used in student } \\
\text { worksheets is easy to } \\
\text { understand }\end{array}$ & 100 & $\begin{array}{l}\text { Respond very } \\
\text { strongly }\end{array}$ \\
\hline 5. & $\begin{array}{l}\text { The terms contained in } \\
\text { student worksheets are easy to } \\
\text { understand }\end{array}$ & 73 & respond \\
\hline 6. & $\begin{array}{l}\text { Images in worksheets } \\
\text { can help understanding chem } \\
\text { ical bonding material }\end{array}$ & 100 & $\begin{array}{l}\text { Respond very } \\
\text { strongly }\end{array}$ \\
\hline 7. & $\begin{array}{l}\text { student worksheets content can } \\
\text { generate motivation to learn }\end{array}$ & 80 & respond \\
\hline 8. & $\begin{array}{l}\text { student worksheets can help } \\
\text { become more active in } \\
\text { participating in teaching and } \\
\text { learning activities }\end{array}$ & 100 & $\begin{array}{l}\text { Respond very } \\
\text { strongly }\end{array}$ \\
\hline 9. & $\begin{array}{l}\text { Student worksheets is } \\
\text { considered interesting or fun }\end{array}$ & 93 & $\begin{array}{l}\text { Respond very } \\
\text { strongly }\end{array}$ \\
\hline 10 & $\begin{array}{c}\text { Fonts (types and sizes) used are } \\
\text { easy to read }\end{array}$ & 93 & $\begin{array}{l}\text { Respond very } \\
\text { strongly }\end{array}$ \\
\hline 11 & $\begin{array}{l}\text { The student worksheets cover is } \\
\text { considered attractive }\end{array}$ & 100 & $\begin{array}{l}\text { Respond very } \\
\text { strongly }\end{array}$ \\
\hline 12 & $\begin{array}{l}\text { Background in accordance with } \\
\text { the color of the writing }\end{array}$ & 93 & $\begin{array}{l}\text { Respond very } \\
\text { strongly }\end{array}$ \\
\hline 13 & $\begin{array}{l}\text { Terms, formulas, and symbols in } \\
\text { student worksheets } \\
\text { are clearly stated }\end{array}$ & 93 & $\begin{array}{l}\text { Respond very } \\
\text { strongly }\end{array}$ \\
\hline 14 & $\begin{array}{l}\text { Student worksheets is considered } \\
\text { to be able to help find out the } \\
\text { application of material } \\
\text { concepts in everyday life }\end{array}$ & 87 & $\begin{array}{l}\text { Respond very } \\
\text { strongly }\end{array}$ \\
\hline & Total & & 100 \\
\hline
\end{tabular}

Science literacy oriented worksheets on the material of chemical bonding can be said to be practical because it gets a positive response from the user of between $73 \%$ to $100 \%$.

On question no. 1 shows that students strongly agree that the developed worksheets are in accordance with the material of chemical bonds. The percentage obtained is $100 \%$. This compliance is in accordance with the validation results of the validator. Validator states very valid for aspects of conformity with basic competencies in the material of chemical bonds.

In terms of interest and attractiveness, the worksheets that were developed received a positive response as seen from the students' answers regarding the attractiveness of student worksheets to questions no. 9, 11, and 12. The percentages obtained for each question in a row are $100 \% ; 93 \%$; and 93\%. The student worksheets are presented with a picture display, a good background that can attract students to learn it. Development of an interesting learning tool is one of the efforts to create enjoyable learning. In terms of convenience in its use, worksheets oriented to scientific literacy in the material of chemical bonds are also said to be practical by students. This can be seen from question no. 2, 4, 5, 6, 10 and 13 which are included in the responding and very responding categories. The percentage obtained in a row is $80 \% ; 100 \% ; 73 \% ; 100 \% ; 93 \%$; and $93 \%$.

In question 2, students state that the worksheet given is easy to understand. This statement is supported by questions 4, 5, 6, 10 and 13. Student worksheets can be easily understood because it is supported by language usage, supporting images, font types, terms, formulas, and symbols used in student worksheets are clear and easy. According to Weidenmann states that images can provide a better understanding when compared to information that is only in the form of text or writing [7]. In addition, the developed student worksheets is said to be practical because the preparation has included instructions for use [7].

Dealing with Question 5, 27\% of students gave a negative response by assuming that the terms in student worksheets were difficult to understand. Understanding of terms in worksheets that are poorly understood by students is when reading the phenomena presented in the student worksheets. In this phenomenon several terms emerged that they did not recognize. This is because all this time learning material in chemical bonds is only a theory that is rarely associated with its application. This statement is supported by the results of observations of student activities while using student worksheets. Table 7 is the result of observations of student activities at the first meeting.

TABLE 7 RESULTS OF OBSERVATIONS OF STUDENT ACTIVITIES AT THE FIRST MEETING

\begin{tabular}{|c|c|c|}
\hline No. & Observed aspects & Percentage \\
\hline 1. & Listen to the teacher's explanation & 3.33 \\
\hline 2. & $\begin{array}{l}\text { Answering questions in student } \\
\text { worksheets (content knowledge) }\end{array}$ & 13,33 \\
\hline 3. & $\begin{array}{l}\text { Observe and read applications } \\
\text { for applying material concepts in } \\
\text { everyday life (scientific context) }\end{array}$ & 6.67 \\
\hline 4 & $\begin{array}{l}\text { Identifying problems in student } \\
\text { worksheets related to phenomena that } \\
\text { are "refractory bricks" (explaining } \\
\text { scientific phenomena) }\end{array}$ & 6.67 \\
\hline 5. & $\begin{array}{l}\text { Formulate hypotheses (explain } \\
\text { scientific phenomena) based on the } \\
\text { phenomenon of "fire-resistant brick" }\end{array}$ & 3.33 \\
\hline 6. & $\begin{array}{l}\text { Collect data by answering questions } \\
\text { contained in student worksheets } \\
\text { (knowledge domain) }\end{array}$ & 6.67 \\
\hline 7. & $\begin{array}{l}\text { Analyzing previously created tables } \\
\text { (interpreting scientific data and } \\
\text { evidence) }\end{array}$ & 13.33 \\
\hline 8. & $\begin{array}{l}\text { Communicate or provide responses or } \\
\text { objections in accordance with } \\
\text { scientific evidence (attitudes towards } \\
\text { science) }\end{array}$ & 10 \\
\hline
\end{tabular}




\begin{tabular}{|c|l|c|}
\hline No. & \multicolumn{1}{|c|}{ Observed aspects } & Percentage \\
\hline 9. & $\begin{array}{l}\text { Summing up and linking it with } \\
\text { hypotheses (interpreting scientific data } \\
\text { and evidence) }\end{array}$ & 3.33 \\
\hline 10 & $\begin{array}{l}\text { Identifying problems in worksheets } \\
\text { related to the phenomenon of "healthy } \\
\text { teeth protected" (explaining scientific } \\
\text { phenomena) }\end{array}$ & 3.33 \\
\hline 11. & $\begin{array}{l}\text { Formulate hypotheses (explain } \\
\text { scientific phenomena) based on the } \\
\text { phenomenon of "healthy teeth } \\
\text { protected" }\end{array}$ & 6.67 \\
\hline 12 & $\begin{array}{l}\text { Design trial procedures (evaluate and } \\
\text { design scientific investigations) }\end{array}$ & 13.33 \\
\hline 13. & $\begin{array}{l}\text { Experiment with enthusiasm and } \\
\text { earnest (procedural knowledge and } \\
\text { attitude towards science) }\end{array}$ & 6.67 \\
\hline 14. & $\begin{array}{l}\text { Doing irrelevant activities (playing } \\
\text { cellphone, talking with friends, etc.) }\end{array}$ & 3.33 \\
\hline & \multicolumn{1}{|c|}{ Total } \\
\hline
\end{tabular}

Based on table 7 it can be seen that in the first meeting it was described that students needed a long time, which was $6.67 \%$ to observe and read and $6.67 \%$ to identify the problems presented in the student worksheets. This is related to the ability of the context domain students are still lacking.

In addition to the aspects of attractiveness and convenience, the thing that needs to be considered again is the aspect of the ability of student worksheets to motivate students. Based on table 4.7 question no. 3, 7, 8, and 14 are questions that represent students' opinions on worksheets because they can motivate them to learn. The percentage obtained in a row is $100 \% ; 20 \% ; 100 \% ; 100 \% ; 87 \%$; and $80 \%$.

In the 7 th statement in table 6 , the results obtained amounted to $80 \%$. This shows that $20 \%$ of students consider that the worksheets developed cannot generate their motivation in learning. Students assess that the developed worksheet can provide motivation to learn.

Experiment activities carried out can provide a real picture of the material. This makes students motivated to study chemical bonding material. Experiment activities carried out are able to stimulate students to be enthusiastic in learning science. This statement corresponds to PISA 2015 on domains of scientific literacy attitudes that students are expected to have an attitude of interest in science [2]. One manifestation of interest in science is students curiosity about science issues. As for one of the issues raised in student worksheets is an environmental issue that exists in everyday life. This is supported by the results of observations of student activities at the second meeting shown by table 8
TABLE 8 RESULTS OF OBSERVATIONS OF STUDENT ACTIVITIES AT THE SECOND MEETING

\begin{tabular}{|c|c|c|}
\hline No. & Observed aspects & Percentage \\
\hline 1. & $\begin{array}{l}\text { Experiment with enthusiasm and earnest } \\
\text { (procedural knowledge and attitude } \\
\text { towards science) }\end{array}$ & 36.67 \\
\hline 2. & $\begin{array}{l}\text { Students write experimental data by } \\
\text { presenting graphs / tables (attitudes toward } \\
\text { procedural science and knowledge) }\end{array}$ & 6.67 \\
\hline 3. & $\begin{array}{l}\text { Analyze experimental results data } \\
\text { (interpret data and scientific evidence) by } \\
\text { answering questions on } \\
\text { worksheets }\end{array}$ & 13.33 \\
\hline 4 & $\begin{array}{l}\text { Communicate / provide responses or } \\
\text { objections in accordance with } \\
\text { experimental evidence (attitudes toward } \\
\text { science) }\end{array}$ & 16.67 \\
\hline 5. & $\begin{array}{l}\text { Summarize experimental results data and } \\
\text { relate them to hypotheses (interpret } \\
\text { scientific data and evidence) }\end{array}$ & 6.67 \\
\hline 6. & $\begin{array}{l}\text { Students read the phenomena presented in } \\
\text { the worksheet regarding environmental } \\
\text { phenomena. (attitude awareness domain } \\
\text { and context domain) }\end{array}$ & 3.33 \\
\hline 7. & $\begin{array}{l}\text { Students work on questions related to } \\
\text { phenomena (knowledge and } \\
\text { environmental care attitude) }\end{array}$ & 13.33 \\
\hline 8. & $\begin{array}{l}\text { Doing irrelevant activities (playing } \\
\text { cellphone, talking with friends, etc.) }\end{array}$ & 3.33 \\
\hline & Total & 100 \\
\hline
\end{tabular}

Based on the data in table 8 , it is known that at the second meeting (ion bonding material) the percentage of analyzing activity was $13.33 \%$ then at the next meeting (covalent bonding material) the percentage of activity was $10 \%$. This shows students' enthusiasm for learning so that activities take place faster than before.

Students argue that the developed worksheets can help them become more active in teaching and learning activities. Experiment activities carried out make learning more active. Students are guided actively to design experiments, conduct experiments with the help of developed student worksheets. The results of observations of student activities show a higher percentage of learning activities than irrelevant activities. The most dominant learning activities are designing and conducting experiments. Based on the data in Tables 7 and 8, the percentage of designing and conducting experiments at the first meeting was $13.33 \%$ and $6.67 \%$, and at the second meeting was $36.67 \%$.

The worksheets that are developed meet the principles of learning that can motivate students. One way to motivate students through learning is to provide goals and benefits to students. Scientific literacy oriented worksheets give positive responses about this. Of the 15 students who were subjected to limited trials, $87 \%$ of students said that worksheets could help connect material learned in class to their usefulness in daily life. The statement can be viewed from the students' answers to the following worksheets: 


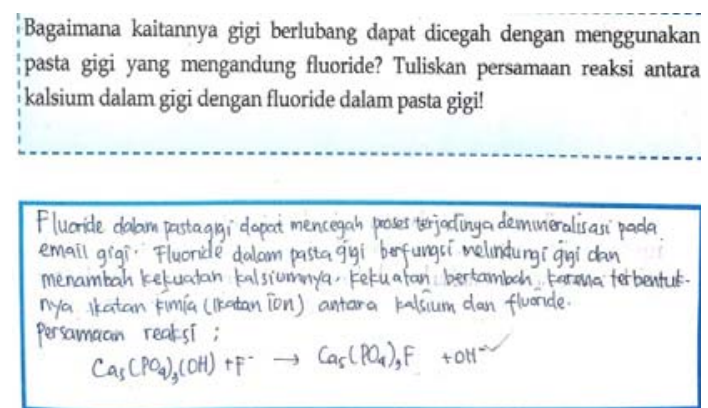

Fig 3. Students' answers to student worksheets

\section{CONCLUSION}

Based on the results and discussion of research data that has been done it can be concluded that the scientific literacy worksheets on the material of chemical bonds are said to be valid and practical because they meet the following criteria:

A. Fulfill validity both valid in content and construct. The percentage of content validity for each aspect is between $80 \%$ and $93.33 \%$ with valid and very valid categories. The construct validity has also been said to be valid with the acquisition of percentage results between $73.33 \%$ to $93.33 \%$ in the valid and very valid categories.

B. Meet the practicality in terms of students' responses to the worksheets developed. Students give a positive response to worksheets oriented to scientific literacy in the material of chemical bonds with the results of the percentage of responses of students who are between $73 \%$ to $100 \%$ in the responding and very responding categories.

\section{REFERENCES}

[1] Toharudin, Uus \& Hendrawati, Sri. Membangun Literasi Sains Peserta Didik. Bandung: Anggota IKAPI, 2011.

[2] OECD. PISA 2015 Assessment and Analytical Framework: Science, Reading, Mathematic and Financial Literacy, PISA, OECD Publishing, Paris, 2016.

[3] Vienurillah, N., \& Dwiningsih, K. Pengembangan Lembar Kegiatan Siswa Berorientasi Literasi Sains pada Submateri
Faktor-Faktor yang Mempengeruhi Laju Reaksi. Unesa Journal of Chemistry Education, 2016, pp. 258-263.

[4] Thiagarajan,S., Semmel,D.S \& Semmel,M.I. Instructional Development for Training Teachers of Expectional Children. Minneapolis, Minnesota: Leadership Training Institute/Special Education, University of Minnesota, 1974.

[5] Riduwan. Skala Pengukuran Variabel-Variabel Penelitian. Bandung : CV Alfabeta, 2015.

[6] Lampiran Permendikbud. Peraturan Menteri Pendidikan dan Kebudayaan Republik Indonesia Nomor 59 Tahun 2014 tentang Kurikulum Sekolah Menengah Atas/Madrasah Aliyah. Jakarta: Menteri Pendidikan dan Kebudayaan RI, 2014.

[7] Departemen Pendidikan Nasional. Panduan Pengembangan Bahan Ajar. Jakarta: Departemen Pendidikan Nasional Direktorat Jenderal Manajemen Pendidikan Dasar dan Menengah Direktorat Pembinaan Sekolah Menengah Atas, 2008.

[8] Nieveen,N.\& Plomp,T. Educational Design Research -Part A: An Intruduction. Enschede, the Netherlands: SLO, 2013.

[9] Nur, Muhammad. Teori-Teori Perkembangan. Surabaya: institut Keguruan dan Ilmu Pendidikan Surabaya, 1998

[10] Aisyah \& Dwiningsih, K. Pengembangan Lembar Kegiatan Siswa (LKS) Berorientasi Literasi Sains Pada Materi Larutan Elektrolit Dan Nonelektrolit. UNESA Journal of Chemical Education, 2017, Vol. 6, No. 2, pp 329-333

[11] Nawangati ,Ari Zuhro Irma \& Dwiningsih K. Pengembangan Lembar Kegiatan Siswa (LKS) Berorientasi Inkuiri Terbimbing untuk Melatihkan Kemampuan Literasi Sains pada Materi Kesetimbangan Kimia. UNESA Journal of Chemical Education, 2017, Vol 6, No. 2 pp. 334-338

[12] Stefanova , Yordanka, Maria Minevska Dan Svetla Evtimova. Scientific Literacy: Problems Of Science Education In Bulgarian School. Problems of Education in the $21^{\text {st }}$ Century, 2010, Vol 19, No. 2 Pp. $113-118$

[13] Solfarina. Peningkatan Pemahaman Konsep Ikatan Kimia Mahasiswa Calon Guru Melalui Pembelajaran Berbasis ELearning. Jurnal Chemica , 2012, Vol. 13, 1 -10.

[14] Holbrook Jack. " The Meaning of Scientific Literacy". International Journal of Environmental \& ScienceEducational, 2009, 4 (3), 144-150.

[15] Ramdaniyah, Ike F. Nisfiatin, \& Dwiningsih, K. Penerapan LKS Berbasis Literasi Sains melalui Model Inkuiri Terbimbing untuk Meningkatkan Literasi Sains Siswa pada Submateri Faktor-Faktor yang Mempengaruhi Laju Reaksi. Unesa Journal of Chemistry Education, 2016, Vol.6 , No. 1, pp.59-65. 